\title{
Loss functions for structural flood mitigation measures
}

\author{
C Berning, LA Du Plessis* and MF Viljoen \\ PO Box 339, Department of Agricultural Economics, University of the Free State, Bloemfontein, 9300
}

\begin{abstract}
The paper aims at discussing the methodology used to develop loss functions for flood mitigation measures, using historic data of flood damage to infrastructure. The main determinants of the extent of damage are the size of the flood and the length of the infrastructure within the boundaries of the flood-line. In regression analysis, flood peak was used as the independent variable in the Cobb-Douglas functions to depict the relationship between damage and flood peak. The Mfolozi flood-plain in Northern KwaZulu-Natal served as the study area. Loss functions for infrastructure, for ex ante estimation of damage to infrastructure, were developed for inclusion in a flood damage simulation model (FLODSIM) developed by the Department of Agricultural Economics of the University of the Orange Free State in collaboration with the Water Research Commission. Loss functions were determined for spillways, levees, tramlines, public roads, drains and bridges.
\end{abstract}

\section{Introduction}

The aim of this paper is to discuss the methodology used to develop loss functions for infrastructure to determine the potential flood damage to infrastructure (spillways, levees, tramlines, public roads, drains and bridges) before floods occur. Loss functions define the relationship between flood damage and certain characteristics of a flood. Flood damage to infrastructure is assessed as the cost of repairing infrastructure to that of pre-flood conditions. The two most significant factors that determine the extent of flood damage are the size of the flood, in terms of volume of water that flows through the flood-plain, and the length of roads, drains, and other structures, within the boundaries of the flood-line. Cobb-Douglas functions were used to depict the relationship between flood peak and damage to infrastructure. The Mfolozi flood-plain in the coastal region of Northern KwaZulu-Natal was used as a study area. The Mfolozi co-operative bears the cost of repairing spillways, levees and tramlines, as well as public roads, drains and bridges. The cost of repairing private roads, drains and bridges, for which farmers are responsible, was not included in the loss functions for infrastructure presented in this article. The loss functions for infrastructure were included in a flood damage simulation model for irrigation areas in South Africa (FLODSIM) developed by the Department of Agricultural Economics of the University of the Free State in collaboration with the Water Research Commission (Du Plessis et al., 1998).

The paper commences with background information on the infrastructure found in the Mfolozi flood-plain and the causes of damage to the infrastructure. In the third section the steps that were followed to determine loss functions for infrastructure are given. This is followed by a short discussion of the results obtained. Conclusions are given in the final section of the paper.

\section{Infrastructure in the Mfolozi flood-plain and the causes of damage}

The transportation network includes roads, bridges and tramlines. Farmers' houses in higher areas are linked to farms in the flood-

* To whom all correspondence should be addressed.

푱(051) 401-2721; fax (051) 448-0692; e-mail: anton@landbou.uovs.ac.za Received 10 December 1998; accepted in revised form 4 September 2000. plain by approximately $70 \mathrm{~km}$ of gravel roads. The co-operative is responsible for maintenance and reparation of approximately 34 kilometres of roads. Several bridges, such as the Domoina-, Wilson's Cannal-, 31/2-, Low Level- and Monzi Bridge, are also maintained by the co-operative. A tramline network of 92 kilometres is used for transporting sugar cane to the mill. Annually, the network transports more than 650000 tons of sugar cane to the mill over an average distance of $16 \mathrm{~km}$ (Department of Environmental Affairs, 1986). The marshalling yard lies to the north of the Mfolozi River and it is to be expected that there will be limited damage only in the case of large floods (Bosch and Associates, 1995).

The water related works include levees, spillways and drains. Levees, with an average height of $3 \mathrm{~m}$, are maintained to prevent inundation caused by the overflow of the banks of the Mfolozi River and the resultant damage to farms. For the area where farms border the river, the whole South Bank and the largest part of the North Bank of the Mfolozi River, have levees. Besides the levees on a large part of the northern bank of the Msunduzi River, there are also the Mavuya and Mokana Banks and the levees on both sides of the Jamp Estate and Wilson's Channel. After the flood, the drainage network facilitates the removal of water from the farms. A drainage network of approximately $115 \mathrm{~km}$ drains storm water from farms in the flood-plain to the Mfolozi and Msunduzi Rivers (Department of Environmental Affairs, 1986). Farmers are responsible for private drains of approximately $32 \mathrm{~km}$, while the remaining $83 \mathrm{~km}$ are maintained by the co-operative (De Jager, 1997). There are two spillways carrying surplus floodwater of the Mfolozi River to the Msunduzi River to prevent overflowing of the main bank of the Mfolozi River. The length of the emergency spillway is $120 \mathrm{~m}$. The longest spillway, which was completed after the Domoina flood of 1984, is $1000 \mathrm{~m}$ (Department of Environmental Affairs, 1986). The purpose of the spillway is to channel the floodwater evenly over sugar cane fields in the direction of the Msunduzi River. Furthermore, the spillway also decreases the speed whereby floodwaters flows across the flood-plain and less sand is carried by the water and deposited on low-lying farms. The spillway starts functioning when discharge exceeds approximately $760 \mathrm{~m}^{3} / \mathrm{s}$, i.e. when the flow of the Mfolozi River reaches the level of the spillway. As the flow increases, a portion of the flow is released over the spillway to the Msunduzi River and onto the flood-plain. The ratio that is diverted becomes greater as 
TABLE 1

Direct flood damage to all infrastructure categories in the Mfolozi flood-plain for actual floods since 1984 (1994 values)

\begin{tabular}{|c|c|c|c|c|c|c|c|c|}
\hline \multirow{2}{*}{$\begin{array}{c}\text { Flood } \\
\text { peak } \\
\left(\mathbf{m}^{3} / \mathbf{s}\right)\end{array}$} & \multirow{2}{*}{$\begin{array}{c}\text { Date } \\
\text { (year) }\end{array}$} & \multicolumn{7}{|c|}{ Flood damage (R'000) } \\
\cline { 3 - 9 } & & Drains & Levees & Roads & Tramlines & Spillways & Bridges & Total \\
\hline $\mathbf{8 0 0}$ & -- & 0 & 0 & 0 & 0 & 0 & 0 & 0 \\
$\mathbf{2 6 0 0}$ & $\mathbf{1 9 9 3}$ & 141 & 0 & 30 & 80 & 60 & 14 & 325 \\
$\mathbf{5 1 4 8}$ & $\mathbf{1 9 8 9}$ & 316 & 0 & 240 & 160 & 146 & 47 & 909 \\
$\mathbf{6 ~ 2 0 0}$ & $\mathbf{1 9 8 7}$ & 350 & 932 & 256 & 176 & 160 & 50 & 1924 \\
$\mathbf{1 5 4 4 5}$ & $\mathbf{1 9 8 4}$ & 3845 & 10075 & 6320 & 7820 & 7405 & 2685 & 38150 \\
\hline
\end{tabular}

Source: Bosch and Associates (1995)

the flood flow increases. If the flow increases to more than $7000 \mathrm{~m}^{3} / \mathrm{s}$, the banks of the Lower Mfolozi River would be saturated and failure would occur, rapidly causing disastrous flooding (Bosch and Associates and Conningarth Consultants, 1991).

Rivers under flood often carry debris, which lead to blockage of the narrower parts of the rivers and cross-sections under bridges. This often causes severe damage or total destruction to bridges, and can lead to the almost immediate overflow of riverbanks. Fur-

TABLE 2

Estimated flood peaks and direct flood damage to infrastructure for various return periods (1994 values)
(A)

Estimated flood peaks and flood damage to infrastructure for various return periods (1994 values) ${ }^{1}$

\begin{tabular}{|c|c|c|c|c|}
\hline $\begin{array}{c}\text { Return } \\
\text { period } \\
\text { (year) }\end{array}$ & $\begin{array}{c}\text { Flood } \\
\text { peak } \\
\left(\mathbf{m}^{3} / \mathbf{s}\right)\end{array}$ & $\begin{array}{c}\text { Flood } \\
\text { damage } \\
\text { (R'000) }\end{array}$ & $\begin{array}{c}\text { Return } \\
\text { period } \\
\text { (year) }\end{array}$ & $\begin{array}{c}\text { Flood } \\
\text { peak } \\
\left(\mathbf{m}^{3} / \mathbf{s}\right)\end{array}$ \\
2 & 1302 & 14 & 10 & 3150 \\
5 & 2996 & 395 & 20 & 4720 \\
10 & 4490 & 760 & 50 & 7970 \\
15 & 5700 & 1100 & 100 & 9570 \\
20 & 6649 & 2500 & 200 & 11280 \\
25 & 7513 & 3600 & RMF & 15450 \\
50 & 10750 & 11000 & & \\
100 & 15206 & 38150 & & \\
\hline
\end{tabular}

${ }^{1}$ Source: Bosch and Associates (1995)

${ }^{2}$ Source: Cai and Myburgh (1998)
(B)

Return periods with corresponding flood peak values used in the present study ${ }^{2}$

Flood

$\left.\mathrm{m}^{3} / \mathbf{s}\right)$

150

720

970

9570

1280

15450

\section{Development of loss functions for infrastructure}

Flood damage estimates for drains, levees, roads, tramlines, spillways and bridges for the major floods between 1984 and 1993 are presented in Table 1. Estimates were based on the actual flood repair cost for floods, which occurred in the past, and were adapted to present conditions (improved levees and spillway) and escalated to 1994 values (Bosch and Associates, 1995). Damage does not occur until the flood peak exceeds $800 \mathrm{~m}^{3} / \mathrm{s}$.

In part A of Table 2 the respective flood peaks for various return periods as well as the estimated flood damage according to Bosch and Associates (1995) are shown. In part B of Table 2 these values are compared to flood peaks for different return periods (floods with different probabilities of occurrence) that were calculated by the Department of Water Affairs and Forestry (DWAF) for the purposes of this study. The regional maximum flood (RMF) was assumed to be a 1000 -year flood.

From the comparison above, it can be seen that the return periods assigned to different flood peaks by Bosch and Associates (1995) and DWAF (Cai and Myburgh, 1998) respectively, were not similar. This implies that the recorded values do not exist for the flood peak values used in the present study. Hence, 
values for damage to infrastructure for the flood peak values relevant in the present study, had to be calculated from the available data in Table 1 . For each infrastructure category the recorded values in Table 1 were plotted and a trend line (binomial function) was fitted through these points. The trend line was used to estimate the damage values for the relevant flood peaks. The results are presented in Table 3 .

From the estimates in Table 3, it was possible to calculate the flood damage per metre for all infrastructure categories except bridges. Table 4 gives the length of the infrastructure within the boundaries of the flood lines, which depends on the return period of the flood. The length of levees and spillways remained constant for all return periods as a result of the assumptions that were made in the flood line numerical model (Cai and Myburgh, 1998).

From the total direct damage in Table 3 and the length of infrastructure in Table 4, it was possible to calculate the direct damage per metre. Table 5 shows the calculated direct damage per metre for the respective infrastructure categories for different flood peaks.

The main determinants of the extent of flood damage to infrastructure are flood peak and the length of drains, levees, roads, tramlines and spillways in the flood-plain. These relationships can be depicted by loss functions. In regression analysis, flood peak $(\mathrm{F})$ was used as an independent variable in a Cobb-Douglas function to depict the relationship between damage and flood peak. Since damage to drains, levees, roads, tramlines and spillways is influenced by the length of each within the flood-plain, the loss functions of these categories were based on per metre direct damage values in Table 5. Loss functions of bridges and total infrastructure were based on total direct damage values in Table 3. Estimated loss functions are presented in Table 6.

\section{Results}

Figure 1 is a graphic representation of the loss functions for different infrastructure categories that depict direct flood damage per metre of infrastructure at different flood peaks.

Figure 1 shows that the direct damage per metre to spillways is the greatest. The length of spillways is, however, the shortest. As was indicated in Table 1, total direct damage to levees is the highest. Figure 2 shows the loss function for total direct damage to infrastructure at different flood peaks.

\section{Conclusion}

The well-developed infrastructure in the Mfolozi flood-plain effectively decreases flood damage to sugar cane, especially during smaller floods. This benefit is, however, partially offset by the considerable amount of money that is spent on annual maintenance and repairs after destructive floods. It was found that there is a higher correlation between the extent of flood damage to infrastructure and the size of a flood than between damage to infrastructure and the depth and duration of inundation. With regard to drains, levees, roads, tramlines and spillways, the length of each within the flood-plain was determined for different flood peaks, making it possible to calculate damage per metre. The latter was used to determine the loss functions, which took the
TABLE 4

Length of infrastructure within the boundaries of flood lines for relevant return periods

\begin{tabular}{l|c|c|c|c|c|c|}
\multirow{2}{*}{$\begin{array}{l}\text { Flood } \\
\text { peak } \\
\left(\mathbf{m}^{3} / \mathbf{s}\right)\end{array}$} & \multirow{2}{*}{$\begin{array}{l}\text { Return } \\
\text { period }\end{array}$} & \multicolumn{5}{|c|}{ Length (m) } \\
\cline { 3 - 7 } & & Drains & Levees & Roads & Rail & Spillways \\
$\mathbf{3 1 5 0}$ & $\mathbf{1 0}$ & 55540 & 46010 & 20000 & 30870 & 1120 \\
$\mathbf{4 7 2 0}$ & $\mathbf{2 0}$ & 57050 & 46010 & 25040 & 35460 & 1120 \\
$\mathbf{7 9 7 0}$ & $\mathbf{5 0}$ & 57960 & 46010 & 29730 & 46260 & 1120 \\
$\mathbf{9 5 7 0}$ & $\mathbf{1 0 0}$ & 58090 & 46010 & 32050 & 49760 & 1120 \\
$\mathbf{1 1 2 8 0}$ & $\mathbf{2 0 0}$ & 58320 & 46010 & 33390 & 52690 & 1120 \\
$\mathbf{1 5 4 5 0}$ & RMF & 59660 & 46010 & 34260 & 55000 & 1120 \\
& & & & &
\end{tabular}

Source:FLODSIM, 1998 [Land use, roads, tramways, levees, drainage systems and rivers were digitised from 1:10 000 orthophotos created from 1979 photography, which were updated with information derived from 1996 air photos and digital data (Du Plessis et al., 1998)].

Estimated direct flood damage per metre for infrastructure categories in the Mfolozi flood-plain for relevant flood peaks (1994 values)

\begin{tabular}{|c|c|c|c|c|c|}
\hline \multirow{2}{*}{$\begin{array}{l}\text { Return } \\
\text { period }\end{array}$} & \multicolumn{5}{|c|}{ Flood damage $(R / m)$} \\
\hline & Drains & Levees & Roads & Tramlines & Spillways \\
\hline 10 & 3 & 0 & 4 & 0 & 72 \\
\hline 20 & 5 & 0 & 9 & 0 & 121 \\
\hline 50 & 14 & 36 & 34 & 24 & 918 \\
\hline 100 & 22 & 64 & 56 & 42 & 1745 \\
\hline 200 & 32 & 98 & 84 & 63 & 2810 \\
\hline RMF & 64 & 219 & 184 & 142 & 6612 \\
\hline
\end{tabular}

\begin{tabular}{|c|c|c|}
\hline \multicolumn{3}{|c|}{$\begin{array}{c}\text { TABLE } 6 \\
\text { Loss functions for infrastructure categories in the } \\
\text { Mfolozi flood-plain }\end{array}$} \\
\hline Infrastructure & Loss function\# & $\begin{array}{l}\text { Adjusted } \\
\text { coefficient of } \\
\text { determination } \\
\left(\mathbf{R}^{2}\right)\end{array}$ \\
\hline $\begin{array}{l}\text { Drains } \\
\text { Levees } \\
\text { Roads } \\
\text { Tramlines } \\
\text { Spillways } \\
\text { Bridges } \\
\text { Total }\end{array}$ & $\begin{array}{l}\mathrm{D}_{\mathrm{D}}=\left(6.12^{*} 10^{-07}\right) * \mathrm{~F}^{1.9020} \\
\mathrm{D}_{\mathrm{L}}=\left(1.45^{*} 10^{-14}\right)^{*} \mathrm{~F}^{3.8948} \\
\mathrm{D}_{\mathrm{R}}=\left(9.17^{*} 10^{-09}\right)^{*} \mathrm{~F}^{2.4563} \\
\mathrm{D}_{\mathrm{T}}=\left(1.86^{*} 10^{-14}\right)^{*} \mathrm{~F}^{3.8167} \\
\mathrm{D}_{\mathrm{S}}=\left(1.53^{*} 10^{-09}\right) * \mathrm{~F}^{3.0309} \\
\mathrm{D}_{\mathrm{B}}=\left(9.92^{*} 10^{-11}\right)^{*} \mathrm{~F}^{3.2145} \\
\mathrm{D}_{\text {TOT }}=\left(3.76^{*} 10^{-09}\right)^{*} \mathrm{~F}^{3.1151}\end{array}$ & $\begin{array}{l}0.983 \\
0.917 \\
0.997 \\
0.833 \\
0.979 \\
0.984 \\
0.982\end{array}$ \\
\hline \multicolumn{3}{|c|}{$\begin{array}{l}\text { \#The F-test statistic and coefficients of all estimated functions } \\
\text { are significant at } 5 \% \text { levels } \\
\text { D: Direct damage }(1994 \text { values })\left\{D_{D}, D_{L}, D_{R}, D_{T} \text { and } D_{s} \text { in }\right. \\
\left.(R / m) ; D_{B} \text { and } D_{T 0 T} \text { in }\left(R^{\prime} 000\right)\right\} \\
\text { F: Flood peak }\left(\mathrm{m}^{3} / \mathrm{s}\right)\end{array}$} \\
\hline
\end{tabular}




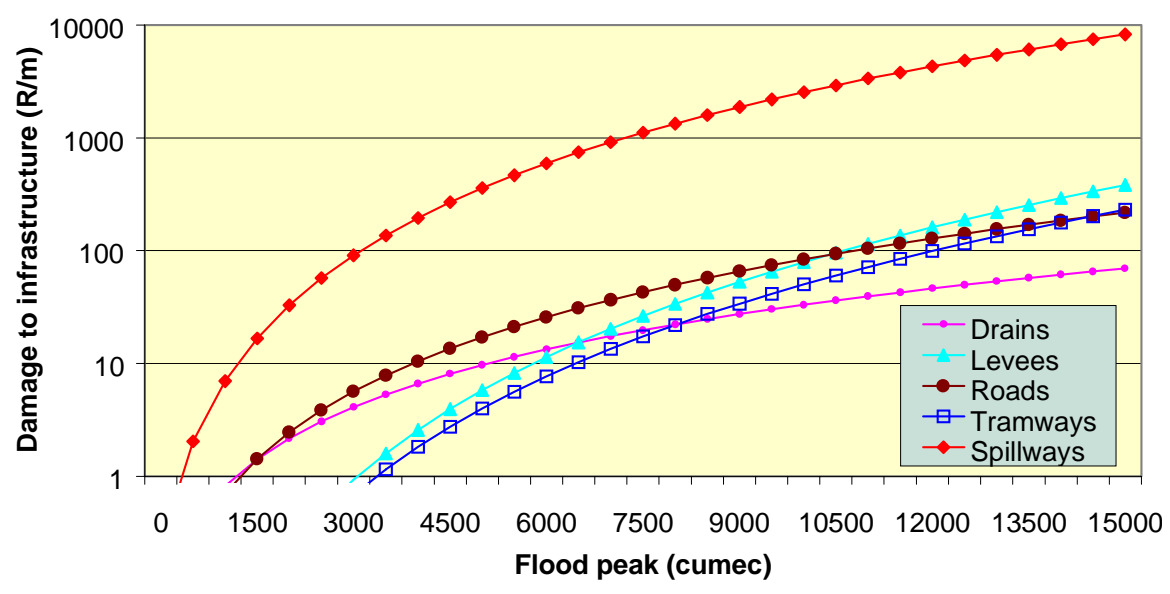

Figure 1

Loss functions for different infrastructure categories in the Mfolozi flood-plain (1994 values)

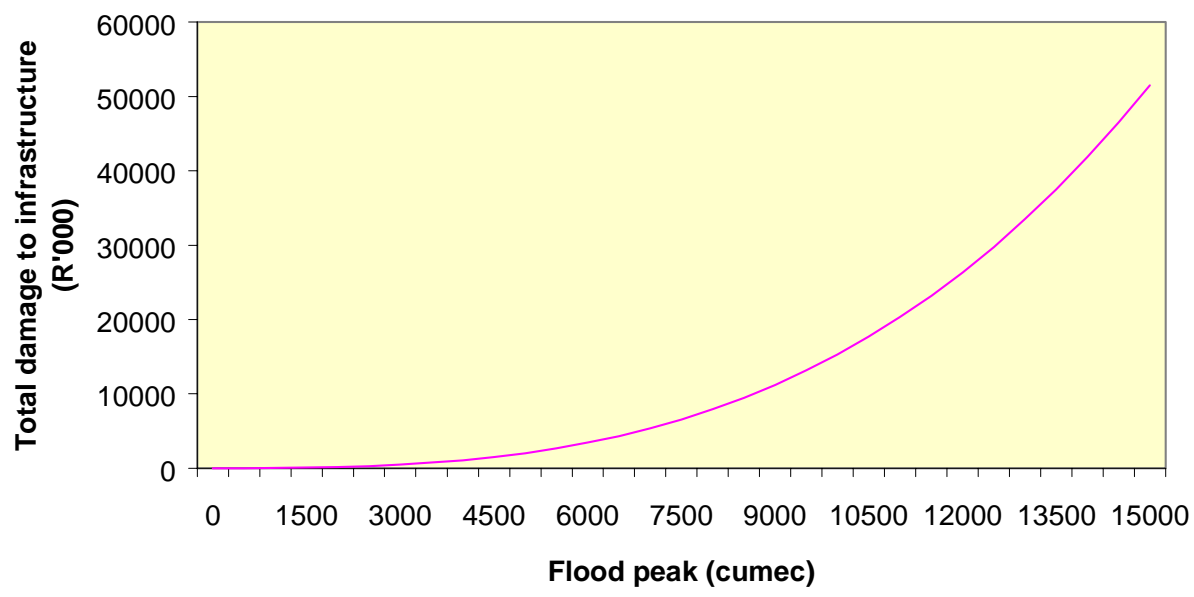

Figure 2

Loss function for total direct flood damage to infrastructure in the Mfolozi flood-plain (1994 values)

form of a Cobb-Douglas function with flood peak being the only independent variable. Since loss functions were calculated per metre, they can be used to determine potential flood damage if additional infrastructure should be constructed in the flood-plain.

\section{Acknowledgements}

Financial support from the WRC to facilitate the research is acknowledged. Financial support from the Centre for Science Development is also acknowledged. Opinions expressed and conclusions reached are those of the authors and should not be construed as being those of the Centre of Science Development and the WRC

\section{References}

BOSCH AND ASSOCIATES INCORPORATED AND CONNINGGARTH CONSULTANTS (1991) Mfolozi Co-operative: Report on Economic Feasibility of Flood Control Structures. Project No. 493/46. Durban.
BOSCH AND ASSOCIATES SA (Pty) Ltd (1995) Final Report on the Inundation of the Lower Mfolozi Flood Plain. Project No 493/46. Durban.

BOSCH AND ASSOCIATES SA (Pty) Ltd (1995) Report on Probability of Flood Damage and Repair Costs. Project No 493/66. Durban.

CAI R and MYBURGH NJ (1998) Lower Mfolozi Flood Plain Floodline Numerical Model. Report No. W230/10/HH01. Department of Water Affairs and Forestry, Pretoria.

DE JAGER G (1997) Personal communication. Drainage manager of Mfolozi Co-operative Sugar Planters.

DEPARTMENT OF ENVIRONMENTAL AFFAIRS (1986) Report of the Ad Hoc Mfolozzi Sand Plain Planning Committee. Natal: Natal Town and Regional Planning Commission.

DU PLESSIS LA, VILJOEN MF, WEEPENER HL and BERNING C (1998) Flood Damage Functions, Models and a Computer Program for Irrigation Areas in South Africa. WRC Report No 889/1/98. Pretoria. PENNING-ROWSELL E (1997) Floods: Causes, Effects and Risk Assessment. Pembroke, Bermuda. 